\title{
CREATIVITY, INNOVATIONS AND FIRM PERFORMANCE IN AN EMERGING TRANSITION ECONOMY ${ }^{1}$
}

Despite the longstanding consensus that creativity is the seedbed of innovation, the limited literature in this area fails to explore the contribution of various aspects of creativity to different stages of the innovation process or the mechanisms used by the management to foster the creativity of employees. This paper adopts a more complex strategy in order to highlight the role of creativity in the entire innovation process from the decision to innovate to investment in innovation, the transformation of innovation input into output and the effect of innovation output on productivity. A multi - stage CDM type model encompassing different elements of creativity and practices designed to enhance creative potential is applied to the most recent Community Innovation Survey data. In modelling the management of creativity a distinction is made between decisions of firms to hire creative employees and the methods used to foster creativity of personnel such as multidisciplinary work

* N. Stojčić, Ph. D., Associate professor, Department of Economics and Business Economics, University of Dubrovnik (E-mail: nstojcic@unidu.hr).

** I. Hashi, Ph. D., Full professor with tenure, Business School, Staffordshire University, United Kingdom (E-mail: i.hashi@staffs.ac.uk).

*** Z. Aralica, Ph. D., Senior research associate, The Institute of Economics, Zagreb (E-mail: zaralica@eizg.hr).

The paper was received on October 10th, 2017. It was accepted for publication on February 22nd, 2018.

1 Draft version of the paper was presented on Training Workshop on ' Technology, Growth and Productivity, including KET' which was held from 18 to 19 May in Zagreb 2017, within project named Strengthening scientific and research capacity of the Institute of Economics, Zagreb as a cornerstone for Croatian socioeconomic growth through the implementation of Smart Specialisation Strategy (H2020-TWINN-2015-692191-SmartEIZ). 
teams, financial incentives and training for creativity. The results indicate that employees with creative skills and the adoption of creativity - enhancing methods by the management are important factors for innovation and better performance of enterprises. They also point to sectoral differences in the impact of creativity on innovation.

Keywords: creativity, innovation, productivity, firm behaviour, CDM model

\section{Introduction}

Ever since the work of Schumpeter (1934) the factors moulding innovation have attracted interest of economists. While existing research acknowledges the pivotal role of creativity in the innovation process, the opinions on the channels through which creativity transforms into innovation differ substantially. One of more recent rounds of Community Innovation Survey (CIS), a bi-annual survey on innovation activities of firms in EU member states and some candidate or associated countries paves the way for further research on the creativity-innovation link. The survey asks questions about the efforts of businesses to hire staff with creative skills and the methods used by the management to enhance creativity.

The research on the relationship between creativity and innovations is particularly important in the context of new member states of the European Union. Innovation behaviour of firms in these countries has been investigated from many angles but, to the best of our knowledge, the management of creativity through different stages of innovation process was not subject of much investigation, if any. For the purpose of this research a dataset is obtained for Croatia, the most recent European Union's member state. Over past two decades Croatia has invested significant efforts in rebuilding of a market economy and a knowledge-based society. Recent admission of this country to European Union, one of the most competitive knowledge based societies in the world, makes enhancing of innovation - driven competitiveness an imperative for its policy makers.

Unlike many previous studies, the paper employs a multi-stage modelling approach to examine the role of the efforts to stimulate creativity in the entire process of innovation, from the decision to innovate to the impact of innovation output on productivity. Moreover, a distinction is made between two dimensions of managerial practices to facilitate creativity, the hiring of individuals with creative skills and methods employed within the firm to facilitate creativity of the personnel. The paper is structured as follows. The next section discusses the relationship between innovations, creativity and firm performance. The overview of creativity 
and innovations in Croatian manufacturing and service sectors is presented in section three. The estimation model and methodology are presented in section four. The results of the investigation are discussed in section five. The paper ends with concluding remarks in section six.

\section{Firm performance, innovations and creativity}

Most economists would agree that creativity forms seedbed of innovation. Amabile et al. (2000) define it as an intra-individual cognitive process conducive to production of novel and useful ideas. The ability to combine and reorganise existing knowledge in previously unthought-of ways starts with individual creative efforts but can flourish only in creative environment. From these starting points the research on the role of creativity in innovation process developed in several directions from the organizational behaviour conducive to creativity over creative potential of individual economic sectors to the individual traits and occupational dimension of creativity.

The organizational behaviour literature notes that the creativity emerges through nexus of individual efforts and environmental factors. The research on individual traits of creativity has so far associated number of personality characteristics with creative potential of individuals. These range from the human and intellectual capital to the relational and social capital (Nahaplet and Ghoshal, 1998; Kale, Singh and Perlmutter, 2000). Different experiences, backgrounds and values pave the way for combination of different types of knowledge (Koestler, 1964). Moreover, Florida (2003) notes that the tolerant environments, open to new ideas and newcomers are particularly attractive to the creative class. Such environments are particularly motivating for emergence of innovations.

Cohen and Levinthal (1990) were among first to recognise the role of organizational environment in transformation of creativity into innovations. Later extensions of their research have further confirmed importance of collaborative networks (Björk \& Magnusson, 2009) among individuals within organization as well as between organizations and their external environment for the development of innovations. Baucus et al. (2008) note that the environments encouraging unconventional behaviour, challenging of authority, conflict, competition and risk propensity have highest potential for flourishing of creativity. Tolerance of ambiguity, measures to develop feeling of psychological safety, stronger self-confidence and lack of rigidity lead to the fusion of ideas in creative groups.

It appears that flexible and decentralized organizational culture facilitates creative activities and birth of innovations. Such settings enable flow of informa- 
tion, teamwork and knowledge sharing all of which are conducive to innovations. In addition to that, the motivation for creative behaviour is strongest in dynamic and turbulent environments where rapid and effective responses are required from firms. Such settings encourage experiments and reduce risk aversion thus enabling search for innovations (Yusuf, 2009; Baron and Tang, 2011). Finally, it has been argued by some scholars that intrinsic motivation such as organizational structure that assigns creative individuals on challenging and complex jobs is more conducive to creativity and generation of innovations than extrinsic rewards such as recognitions or monetary incentives (Hackman and Oldham, 1980; Deci and Ryan, 1985).

Managerial skills in creation of environment conducive to the stimulation of talented employees are important for the development of creativity - relevant skills (Amabile, 1988; Swann and Birke, 2005; Cereda et al., 2005). Hiring personnel with creative skills as well as using creative methods developed in firms may facilitate knowledge transfer from one actor to another and increase the local firms' capacity to innovate via national and international networking (Camagni, 1991). The success of this process depends also on leadership styles of business entities (Yoshida et al., 2014). Eisenbeis and Boerner (2013) suggest that transformational leadership has positive effect on the creativity of employees while the dependency of employees on their managers results in opposite. In addition, the presence of various external sources of creativity enhances the potential for the creativity skills within the firm to influence the innovation process. The contribution of educational, cultural and socio - economic factors to the fostering of creativity is in the very foundations of modern knowledge - driven economies (Villalba, 2010; Aldridge and Audretsch, 2010).

Another strand of literature is concerned with the sectoral creative potential. There is evidence that creative industries are beneficial for national and regional economic performance such as employment, growth or technological breakthrough and innovativeness. (Andari et al., 2007). Apart from within sectoral effects, creative industries generate externalities to related sectors through labour mobility, open innovation practices and spillovers between upstream and downstream industries. Empirical evidence from several studies suggest that creative sectors generate more new products and services than other industries but also contribute to the innovation activities of enterprises in other industries (Chapain et al., 2010). The social and cultural importance of creative industries has also been confirmed in Croatia (Švob-Đokić, 2005; Jelinčić and Žuvela, 2013).

Finally, the last strand of literature investigated the role of creative occupations in innovation process. Evidence across the European Union signals that individuals employed in creative occupations positively contribute to the overall productive efficiency (Marrocu and Paci, 2012). Moreover, they contribute to 
the development of new products and processes (Lee and Drever, 2012; Lee and Rodriguez-Pose, 2013).

Although innovation literature over recent years developed in several directions little reference has been made to the role of creativity in innovation process. One line of research pointed to the importance of comprehensive multi-stage approach to the analysis of innovation process (Loof and Heshmati, 2002, Hashi and Stojcic, 2013) while the open innovation literature revealed the importance of horizontal and vertical spillovers (von Hippel, 1988; Cohen et al., 2002; Chesbrough ,2006; Halpern and Murakozy, 2012). The rationale for and the validity of existing innovation subsidy schemes has been challenged by findings that the propensity to innovate and innovation expenditure increase with access to public finance (Klomp and van Leeuwen, 2001) while the commercialisation of innovations decreases (Hashi and Stojcic, 2013). There is also ample evidence pointing to the differences in the innovation process between different economic sectors (Castellacci, 2008; Ettlie and Rosenthal, 2011).

\section{Creativity and innovations in Croatian manufacturing and service sectors}

In 2016, Croatian government adopted Smart Specialization strategy (S3) as one of leading strategic documents for encouragement of knowledge-intensive growth and employment. Within framework of Croatian Smart Specialization strategy (S3) creativity has been recognized as a crucial source of innovation and creative industries. However, the contribution of creativity to the national economic performance and its exploitation in enterprises has not been subject of much investigation. Rašić-Bakarić, Bačić and Božić, 2015) note that gross value added of creative sectors in Croatia over 2009-2013 recession period rose by 3.5 percent while the gross value added of all other sectors declined for about 4.7 percent. From there it can be seen that facilitating of creativity and transformation of Croatian firms and industries into creative-driven ones can act as an engine of future growth and development.

The empirical analysis in this paper utilises firm level data from the 2010 round of the Community Innovation Survey (CIS), a confidential survey on innovation activities of firms undertaken biannually by Eurostat and national statistical agencies. The important issue about this round of CIS is that it contains two sets of questions on creativity related to hiring of employees with creative skills and the practices used by firms to foster creativity, thus enabling us to explore the role of creativity in the innovation process. For the purpose of this paper we were able to 
access the dataset for Croatia, the latest EU member state. Croatia is an interesting country in terms of innovation history, with its citizens having contributed to the development of science, engineering, warfare, medicine and sports far in excess of their relative size. As the most recent EU member state Croatia faces the challenge of building innovation - driven competitiveness in order for its firms to prosper in knowledge based market such as EU.

Table 1:

INNOVATION ACTIVITIES OF FIRMS IN CROATIA

\begin{tabular}{|l|c|c|}
\hline & Manufacturing & Services \\
\hline Number of firms & 1105 & 1168 \\
\hline Number of firms with positive innovation expenditure & $368(33 \%)$ & $290(25 \%)$ \\
\hline $\begin{array}{l}\text { Number of firms with innovation output } \\
\text { (successful innovators) }\end{array}$ & $244(22 \%)$ & $271(23 \%)$ \\
\hline $\begin{array}{l}\text { Proportion of sales coming from new products among } \\
\text { innovators (\%) }\end{array}$ & 26 & 32 \\
\hline
\end{tabular}

Source: Authors' calculations

To begin with, it is interesting to consider the innovativeness of firms in our sample. Table 1 shows the number and proportion of firms in the sample that have spent their resources on innovation, or produced a new or significantly improved product/process, as well as the proportion of their sales arising from new products or processes. About 33\% of firms in manufacturing, and $25 \%$ of those in services, have invested money in innovation and about $22 / 23 \%$ of them have been successful innovators. Such low figures are at first surprising. However, the official Eurostat figures for West European group of countries are even lower with about 14\% of firms being involved in innovation activities.

Table 2 provides some data on the first dimension of 'creativity', showing the proportion of firms employing people with creative skills. In terms of employing staff with creative skills, there is a clear difference between the innovator firms and non-innovators in almost every skill and in both manufacturing and services (particularly the latter). The majority of innovative firms employ individuals with skills in software development and graphic arts, layout and advertising skills (around 65\% in both sectors) while the proportion of personnel with these skills in the entire sample is relatively low. 
Table 2:

HIRING OF EMPLOYEES WITH CREATIVE SKILLS (\% OF FIRMS)

\begin{tabular}{|l|c|c|c|c|}
\hline & \multicolumn{2}{|c|}{ Manufacturing sector } & \multicolumn{2}{c|}{ Service sector } \\
\hline & All firms & Innovators & All firms & Innovators \\
\hline Graphic arts, layout and advertising skills & 35 & 61 & 36 & 67 \\
\hline Design of objects and services & 34 & 65 & 29 & 69 \\
\hline Multimedia & 22 & 48 & 27 & 60 \\
\hline Web design & 30 & 55 & 35 & 68 \\
\hline Software development & 37 & 69 & 43 & 80 \\
\hline Market research & 33 & 65 & 33 & 63 \\
\hline Engineering & 29 & 60 & 20 & 42 \\
\hline $\begin{array}{l}\text { Mathematics, statistics and database } \\
\text { management }\end{array}$ & 26 & 51 & 28 & 62 \\
\hline
\end{tabular}

Source: Authors' calculations

Table 3:

PRACTICES TO STIMULATE CREATIVITY OF EMPLOYEES (\% OF FIRMS)

\begin{tabular}{|l|c|c|c|c|}
\hline & \multicolumn{2}{|c|}{ Manufacturing sector } & \multicolumn{2}{|c|}{ Service sector } \\
\hline & All firms & Innovators & All firms & Innovators \\
\hline Brainstorming sessions & 5 & 7 & 6 & 11 \\
\hline Multidisciplinary or cross-functional work teams & 5 & 9 & 4 & 9 \\
\hline $\begin{array}{l}\text { Job rotation of staff to different departments or } \\
\text { other parts of the enterprise group }\end{array}$ & 5 & 7 & 3 & 6 \\
\hline $\begin{array}{l}\text { Financial incentives for employees to develop } \\
\text { new ideas }\end{array}$ & 6 & 10 & 5 & 7 \\
\hline $\begin{array}{l}\text { Non-financial incentives for employees to } \\
\text { develop new ideas (free time, public recognition, } \\
\text { more interesting work, etc.). }\end{array}$ & 6 & 8 & 6 & 9 \\
\hline $\begin{array}{l}\text { Training employees on how to develop new } \\
\text { ideas or creativity }\end{array}$ & 5 & 10 & 5 & 8 \\
\hline
\end{tabular}

Source: Authors' calculations

The second dimension of creativity investigated in the survey is the management practices designed to establish a creative environment to develop and foster 
employees' creativity (Table 3). It is evident that far fewer firms have employed methods to promote creativity than it is case with hiring of creative employees though the proportion is larger in innovator firms. To some extent, the absence of a more widespread use of these methods can be explained by the legacy of Croatia's recent socialist past which encouraged conformism and discouraged new but risky practices.

\section{The model}

Our modelling strategy differs from existing studies in that it enables the examination of the role of managerial efforts to stimulate creativity in different stages of the innovation process. A multi-stage model is employed portraying the innovation process in four stages (Crepon et al., 1998). In this model the decision to innovate and the decision on how much to invest in innovation are linked to their determinants in the first two stages of the innovation process. The third stage is a knowledge production function linking innovation input and output while the productivity of a firm is related to the innovation output in the fourth stage. All four stages are also affected by elements representing creativity. This modelling approach addresses common problems in the innovation literature such as selectivity bias and endogeneity bias due to the fact that not all firms in the sample engage in innovation and some innovations are not successful as well as the fact that there are many factors which are related to all four stages of innovation process.

\subsection{General specification of the system model}

If $g_{\mathrm{i}}^{*}$ is an unobserved decision variable of whether or not a firm invests in innovation and $k_{\mathrm{i}}^{*}$ the unobserved level of the firm's investment in innovation, with $g_{i}$ and $k_{i}$ being their observable counterparts, the first two stages of the systemic approach can be defined as follows:

$$
\begin{gathered}
g_{i}=\beta_{0} x_{i}^{0}+u_{i}^{0} \mathrm{~g}_{\mathrm{i}}=\beta_{0} x_{i}^{0}+u_{i}^{0} \\
g_{i}=1 \text { if } g_{\mathrm{i}}^{*}>0, \text { otherwise } g_{i}=0
\end{gathered}
$$


and

$$
\begin{gathered}
k_{i} \mid g_{i}>0=\beta_{1} x_{i}^{1}+u_{i}^{1} \\
k_{i}=k_{i} \text { if } k_{i}^{*}>0, \text { otherwise } k_{i}=0
\end{gathered}
$$

In these expressions $x_{i}^{0}, x_{i}^{1}, \beta_{0}$ and $\beta_{1}$ are vectors of independent variables and their corresponding parameters which reflect the impact of certain determinants on the firm's decision to engage in investment in innovation and on the actual level of expenditure on innovation. The $u_{i}^{0}$ and $u_{i}^{1}$ are random error terms with zero mean, constant variances and assumed not to be correlated with the explanatory variables.

The third stage of the estimation is represented by the following equation:

$$
t_{i}=\alpha_{k} k_{i}+\beta_{2} x_{i}^{2}+u_{i}^{2}
$$

where $t_{i}$ represents the observed level of innovation output, $k_{i}$ represents estimates of innovation input from Equation 2, $\alpha_{k}$ its corresponding parameter, $x_{i}^{2}$ is the vector of other explanatory variables which includes among others the inverse Mill's ratio estimates from Equation 1 and performance variable from the fourth stage to control for selection bias and feedback effect. $\beta_{2}$ is the vector of corresponding parameters while $u_{i}^{2}$ is the random error term with mean zero and constant variance not correlated with explanatory variables.

Finally, the last equation of the model relates the innovation output with the firm's performance.

$$
q_{i}=\alpha_{t} t_{i}+\beta_{3} x_{i}^{3}+u_{i}^{3}
$$

with $q_{i}$ indicating the firm's performance, $t_{i}$ representing estimates of innovation output from Equation 3, $x_{i}^{3}$ and $\beta_{3}$ being vectors of independent variables and their corresponding unknown parameters and $u_{i}^{3}$ being the error term which is assumed to be uncorrelated with explanatory variables.

It is assumed that the disturbance terms from the first two stages of the innovation process are correlated with each other on the basis of the unobservable characteristics of firms. The first two stages are estimated jointly by a generalised tobit model with the maximum likelihood estimation method. This estimation includes all firms in the sample. The third and fourth stages are estimated jointly as a system with a three-stage least squares methodology, using only those firms that have made a positive investment in innovation. The potential endogeneity of 
innovation input and productivity in the third equation and innovation output in the fourth equation is being controlled for with proper instrumentation. Finally, the Mills ratio is calculated from Equation 1 and inserted in the innovation output equation (Equation 3) to control for the potential selection bias arising from the unobserved determinants of the decision to innovate.

\subsection{Definition of variables and specification of the model}

The decision of firms to innovate is the first stage of the innovation process. The dependent variable in this stage is constructed on the basis of whether the firm has reported a positive amount of innovation expenditure in three years prior to survey. Such definition is wider than those conventionally used in innovation literature as it includes internal and external research and development activities, the purchase of equipment, software and knowledge outside of firm, training for the development of innovations, acquisition of the software and equipment for R\&D and acquisition of external knowledge (e.g. patents, licences, know-how etc.). In the second stage, the dependent variable is defined as the natural logarithm of the share of the amount spent on R\&D activitiesA in 2010 (innovation expenditure). In the third stage, the dependent variable is the natural logarithm of the share of sales coming from new products. Finally, the fourth stage of the innovation process is the productivity equation in which the dependent variable is defined as the natural logarithm of labour productivity measured as the turnover per employee in 2010.

Our interest lies primarily in the variables representing managerial efforts to stimulate creativity of their organizations. The impact of creativity on innovation process is modelled in two ways. A set of categorical variables is included for firms that have employed individuals with creative skills in three years prior to the survey. In total, there are eight categories of skills falling within three groups included in the model through corresponding variables: graphics and design (graphic, arts, layout and advertising skills, design of objects and services), creative skills in IT sector (multimedia, web design, software development and market research) and technical creative skills (engineering, mathematics, statistics and database management). Methods employed to encourage and foster creativity are modelled with categorical variables on the basis of answers on question whether firms promoted creativity of their employees through brain-storming sessions, multidisciplinary or cross-functional work teams, job rotation of staff to different departments or other parts of enterprise group, financial incentives for employees to develop new ideas, non-financial incentives, and training of employees on how to develop new ideas or creativity. Also, a categorical variable controls for firms that have followed both aspects of creativity. 
Control variables in the first equation include a measure of firm size, the natural logarithm of the number of employees, categorical variable for firms which are part of an enterprise group, two categorical variables for most important markets of firms (national, the EU and other international markets, with the first treated as the base group), four categorical variables representing factors hampering innovation activities (costs, knowledge, market and no need for innovations) and controls for introduction of marketing and organisational innovations. The innovation expenditure equation, includes in addition two variables for firms that received subsidies for innovation activities from the EU and from national sources while it is assumed that financial constraints and knowledge barriers such as the lack of qualified staff or information about technology or market are the main barriers to innovation activities in this stage.

The explanatory variables in the third stage of the innovation process include firm size, predicted values of innovation input and the inverse Mill's ratio from the second stage, the natural logarithm of labour productivity, two categorical variables controlling for firms that have introduced innovation which was first in Europe and/or first in the world and for firms that have followed open innovation practice in the development of innovations through cooperation with other firms or institutions such as faculties, research institutes, professional associations, etc. in the three years prior to the survey. The list of control variables includes categorical variable for firms that had previous innovation experience through on-going or abandoned innovations, two variables indicating the most important markets of the firm, and controls for receipt of subsidies. We also control for highly important sources of information on innovations such as internal sources, market sources (suppliers, clients, rivals or consultants and private research institutes), institutional sources (high education institutions and public research institutes) and other sources such as journals, fairs, conferences and professional associations. Two variables are included to control for firms that introduced organisational and marketing innovations in three years prior to survey.

The final stage of the innovation process is defined as the productivity equation. Here, the independent variables include: firm size, innovation output from the third stage, control for intra-group knowledge transfer, two controls for the most important markets of firms, ten categorical variables controlling for highly important objectives of innovation activities (including increased range of goods and services, replacement of outdated products and processes, entry to new markets or increase of market share, improvement in the quality of goods and services, improvement in the flexibility for production, increased production capacity, reduction in unit labour, material and energy costs, reduced environmental impact and improved health and safety of employees).

Five categorical variables represent highly important objectives of organisational innovations defined as reduction in time required for response to customer or 
supplier needs, improved ability to develop new products or processes, improved quality of goods and services, reduced unit costs of production and improved communication or information sharing. Finally, three variables are included to control for highly important effects of marketing innovations (which include increasing or maintaining of market share, introduction of products to new customer groups and introduction of products to new geographical markets). Finally, each model includes controls for technological intensity of the industry to which the firm belongs (OECD, 2005). Firms in manufacturing are divided into four groups defined as low (base group), medium low, medium high and high technology intensive industries. Firms in services are divided into two groups defined as low knowledge intensive services (base group) and knowledge intensive services. These variables are intended to control for industry specific effects such as minimum efficient scale or barriers to entry.

\section{Results of investigation}

The results of investigation are presented in this section according to stages of innovation process defined in section 4 . The model for each stage is estimated separately for the manufacturing and service sectors. As our main interest lies in variables modelling creativity, the summary of findings on these variables is also added in the Appendix.

\subsection{The decision to innovate}

Creative skills such as design and software development have a positive effect on decision to innovate in both manufacturing and service sectors while other skills are more important in one or other sector (Table 4). ICT based skills such as graphic arts, layout and advertising, and multimedia influence the decision to innovate within the service sector whereas market research and engineering skills have a positive effect in manufacturing firms. Methods employed by firms to stimulate creativity affect decision to innovate only in the manufacturing sector. The impact of training in the development of new ideas and creativity is positive while that of brainstorming is negative. The latter finding may suggest that employees of firms in the sample are not open to sharing ideas and knowledge with other persons from their environment, perhaps due to the fear of criticism. It can also signal ineffectiveness of management in governing of brainstorming activities within organization. 
Table 4:

\section{THE DECISION TO INNOVATE}

\begin{tabular}{|l|c|c|}
\hline & $\begin{array}{c}\text { Manufacturing } \\
\text { sector }\end{array}$ & $\begin{array}{c}\text { Service } \\
\text { sector }\end{array}$ \\
\hline Firm size & $0.12^{* *}$ & $0.14^{* * *}$ \\
\hline Part of a group & -0.12 & -0.04 \\
\hline Market orientation & & \\
\hline Main market - EU & 0.07 & 0.12 \\
\hline Main market - other countries & 0.19 & -0.12 \\
\hline Factors hampering innovation & 0.08 & $0.23^{* *}$ \\
\hline Cost factors & $0.24^{*}$ & $-0.27^{*}$ \\
\hline Knowledge factors & 0.02 & 0.01 \\
\hline Market factors & $-0.67^{* * *}$ & $-0.62^{* * *}$ \\
\hline $\begin{array}{l}\text { Lack of need for innovation (due to lack of demand for innovations } \\
\text { and already established innovations) }\end{array}$ & & \\
\hline Organisational and marketing innovations & $0.81^{* * *}$ & $0.78^{* * *}$ \\
\hline Marketing innovations & $0.90^{* * *}$ & $1.10^{* * *}$ \\
\hline Organisational innovations & & \\
\hline Creative skills of employees & 0.01 & $-0.49^{* * *}$ \\
\hline Graphic, arts, layout and advertising skills & $0.40^{* * *}$ & $0.46^{* * *}$ \\
\hline Design of objects and services & -0.14 & $0.29^{* *}$ \\
\hline Multimedia & -0.07 & $-0.35^{* *}$ \\
\hline Web design & $0.29^{* * *}$ & $0.77^{* * *}$ \\
\hline Software development & $0.26^{* *}$ & 0.11 \\
\hline Market research & $0.74^{* * *}$ & 0.15 \\
\hline Engineering & -0.14 & 0.02 \\
\hline Mathematics, statistics and database management & $-0.64^{* *}$ & 0.21 \\
\hline Methods to stimulate creativity & 0.14 & 0.28 \\
\hline Brainstorming sessions & 0.18 & -0.06 \\
\hline Multidisciplinary or cross-functional work teams & 0.12 & -0.23 \\
\hline Job rotation of staff to different departments or other parts of group & -0.41 & 0.33 \\
\hline Financial incentives for employees to develop new ideas & $0.58^{* * *}$ & 0.31 \\
\hline Non-financial incentives for employees to develop new ideas & -0.14 \\
\hline Training of employees on how to develop new ideas or creativity \\
\hline Firms that hired employees with creative skills and introduced \\
methods for fostering creativity & & \\
\hline & & -0.05 \\
\hline
\end{tabular}


Table 4 - Continued

\begin{tabular}{|l|c|c|}
\hline & $\begin{array}{c}\text { Manufacturing } \\
\text { sector }\end{array}$ & $\begin{array}{c}\text { Service } \\
\text { sector }\end{array}$ \\
\hline Technological intensity of industry & & \\
\hline Medium-low technology intensive manufacturing & 0.06 & - \\
\hline Medium-high technology intensive manufacturing & 0.10 & - \\
\hline High technology intensive manufacturing & 0.28 & - \\
\hline Knowledge intensive services & - & $0.50^{* * *}$ \\
\hline Number of observations & 1105 & 1168 \\
\hline
\end{tabular}

$(* * *),(* *)$ and $(*)$ indicate statistical significance at $1 \%, 5 \%$ and $10 \%$ levels, respectively.

Larger firms are more likely to innovate which is consistent with the concept of Schumpeter mark II and with earlier literature on innovation behaviour of firms in CEECs (Halpern and Murakozy, 2012; Hashi and Stojcic, 2013). In terms of factors hampering innovation, knowledge factors have positive impact in the manufacturing sector and negative in the service sector. The former finding signals that knowledge constraints force firms to search for new ideas with higher chances of success. A similar explanation holds in the case of positive coefficient on cost factors in service sector. In both sectors the lack of demand for innovations or the continued market dominance of previous innovations has a negative impact on the decision of firms to innovate while firms that have invested in organisational and marketing innovations are more likely to engage in product innovations. Finally, propensity to innovate increases with knowledge intensity in service sector.

\subsection{Innovation investment}

The results for the decision of firms on the amount of innovation investment are presented in Table 5. Hiring of employees with creative skills seems to be important for innovation expenditure of manufacturing firms only. Employees with certain skills such as graphic, arts, layout and advertising, and web design have a negative impact on innovation expenditure, while other skills such as mathematics, statistics and database management have a positive impact. The negative sign for some skills can signal that hiring of personnel with such skills is not essential for type of innovations developed by these firms and thus costly reducing the available funds for investment in innovations. Another likely explanation is the inability of management to optimally exploit creative potential of individuals with these skills. Finally, the obtained finding can be associated with potential mismatch between formal education of employees and required skills of their workplace. Among 
methods used to stimulate creativity, only the training of employees in the service sector has a positive effect.

Table 5:

THE INNOVATION INVESTMENT DECISION

\begin{tabular}{|c|c|c|}
\hline & $\begin{array}{l}\text { Manufacturing } \\
\text { sector }\end{array}$ & $\begin{array}{l}\text { Service } \\
\text { sector }\end{array}$ \\
\hline Firm size & $-0.34 * * *$ & $-0.29 * * *$ \\
\hline Part of a group & 0.13 & -0.17 \\
\hline \multicolumn{3}{|l|}{ Market orientation } \\
\hline Main market - EU & -0.15 & 0.24 \\
\hline Main market - other countries & $0.75 * *$ & -0.09 \\
\hline \multicolumn{3}{|l|}{ Access to subsidies } \\
\hline EU subsidies & 0.11 & $1.51^{* * *}$ \\
\hline National subsidies & $0.90 * * *$ & $1.003 * * *$ \\
\hline \multicolumn{3}{|l|}{ Factors hampering innovation } \\
\hline Cost factors & -0.09 & -0.08 \\
\hline Knowledge factors & 0.07 & 0.27 \\
\hline \multicolumn{3}{|l|}{ Organisational and marketing innovations } \\
\hline Marketing innovations & 0.12 & -0.21 \\
\hline Organisational innovations & 0.19 & -0.63 \\
\hline \multicolumn{3}{|l|}{ Creative skills of employees } \\
\hline Graphic, arts, layout and advertising skills & $-0.48 * *$ & -0.34 \\
\hline Design of objects and services & -0.19 & 0.03 \\
\hline Multimedia & 0.25 & -0.24 \\
\hline Web design & $-0.40 * *$ & 0.30 \\
\hline Software development & 0.25 & -0.61 \\
\hline Market research & 0.22 & -0.33 \\
\hline Engineering & -0.32 & 0.20 \\
\hline Mathematics, statistics and database management & $0.40 * *$ & 0.36 \\
\hline \multicolumn{3}{|l|}{ Methods to stimulate creativity } \\
\hline Brainstorming sessions & 0.66 & 0.10 \\
\hline Multidisciplinary or cross-functional work teams & -0.32 & -0.21 \\
\hline Job rotation of staff to different departments or other parts of group & -0.50 & -0.30 \\
\hline Financial incentives for employees to develop new ideas & -0.21 & -0.59 \\
\hline Non-financial incentives for employees to develop new ideas & -0.25 & $0.87 *$ \\
\hline Training of employees on how to develop new ideas or creativity & 0.19 & -0.36 \\
\hline
\end{tabular}


Table 5 - Continued

\begin{tabular}{|l|c|c|}
\hline & $\begin{array}{c}\text { Manufacturing } \\
\text { sector }\end{array}$ & $\begin{array}{c}\text { Service } \\
\text { sector }\end{array}$ \\
\hline $\begin{array}{l}\text { Firms that hired employees with creative skills and introduced } \\
\text { methods for fostering creativity }\end{array}$ & -0.27 & -0.56 \\
\hline Technological intensity of industry & & \\
\hline Medium-low technology intensive manufacturing & 0.17 & - \\
\hline Medium-high technology intensive manufacturing & 0.17 & - \\
\hline High technology intensive manufacturing & 0.26 & - \\
\hline Knowledge intensive services & - & $0.47^{*}$ \\
\hline Number of observations & 368 & 290 \\
\hline
\end{tabular}

$(* * *),(* *)$ and $(*)$ indicate statistical significance at $1 \%, 5 \%$ and $10 \%$ levels, respectively.

Similar to Loof et al. (2006) our results suggest that larger firms spend smaller amounts of money on innovation. The innovation expenditure increases for manufacturing firms oriented towards markets outside the EU, recipients of national subsidies in both sectors and beneficiaries of EU subsidies in service sector. Finally, the innovation expenditure of firms in service industries increases as they become more knowledge intensive.

\subsection{Innovation output (innovation production function)}

Almost all variables representing different aspects of creativity are significant in both sectors in innovation output equation (Table 6). It seems that creativity leads to the generation of new ideas that enhance the firm's ability to transform innovation input to innovation output. Also, creative skills and methods of fostering creativity act as part of innovation throughput, a set of factors that enable successful transformation of innovation inputs into outputs. Findings on some creative skills suggest, unexpectedly, negative impact on innovation output. Several explanations may be offered for such finding. Hiring of personnel with certain creative skills reduces the amount available for other resources required for successful commercialisation of innovations. These findings may also signal the failure of management to employ existing resources efficiently or the mismatch between formal qualifications and the actual skills of the hired employees. 
Table 6:

INNOVATION OUTPUT EQUATION

\begin{tabular}{|l|c|c|}
\hline & $\begin{array}{c}\text { Manufacturing } \\
\text { sector }\end{array}$ & $\begin{array}{c}\text { Service } \\
\text { sector }\end{array}$ \\
\hline Firm size & $2.04^{*}$ & $1.67^{* *}$ \\
\hline Part of a group & $-1.22^{*}$ & $1.88^{* *}$ \\
\hline Innovation input & $6.76^{*}$ & $6.47^{* *}$ \\
\hline Mills ratio & $0.67^{*}$ & $4.49^{* *}$ \\
\hline Productivity & 0.32 & $-0.49^{* * *}$ \\
\hline Introduction of innovation new to the world & $0.41^{*}$ & 0.19 \\
\hline Open innovation & 0.04 & -0.14 \\
\hline Previous innovation experience & 0.01 & 0.03 \\
\hline Market orientation & & \\
\hline Main market - EU & $1.30^{* *}$ & $-1.98^{* *}$ \\
\hline Main market - other countries & $-5.08^{*}$ & $1.17^{* *}$ \\
\hline Access to subsidies & & \\
\hline EU subsidies & $-6.07^{*}$ & $-9.19^{* *}$ \\
\hline National subsidies & $-1.01^{* *}$ & $-6.04^{* *}$ \\
\hline Sources of information on innovation & & \\
\hline Market & 0.20 & 0.18 \\
\hline Internal sources & 0.02 & -0.11 \\
\hline Institutional sources & 0.11 & -0.13 \\
\hline Other sources & 0.004 & -0.09 \\
\hline Organisational and marketing innovations & & \\
\hline Marketing innovations & $-4.76^{*}$ & $0.47^{*}$ \\
\hline Organisational innovations & -1.06 & $0.48^{*}$ \\
\hline Creative skills of employees & $2.96^{*}$ & $3.62^{* *}$ \\
\hline Graphic, arts, layout and advertising skills & $-1.74^{*}$ & $2.80^{* *}$ \\
\hline Design of objects and services & $2.71^{*}$ & $-0.65^{* *}$ \\
\hline Multimedia & -1.37 & $-2.03^{* *}$ \\
\hline Web design & $-1.39^{*}$ & $3.36^{* *}$ \\
\hline Software development & $2.36^{* *}$ & $-1.99^{* *}$ \\
\hline Market research & $-2.76^{*}$ & $-1.76^{* *}$ \\
\hline Engineering & & \\
\hline Mathematics, statistics and database management & & \\
\hline Methods to stimulate creativity & & \\
\hline Brainstorming sessions & & \\
\hline & & \\
\hline
\end{tabular}


Table 6 - Continued

\begin{tabular}{|l|c|c|}
\hline & $\begin{array}{c}\text { Manufacturing } \\
\text { sector }\end{array}$ & $\begin{array}{c}\text { Service } \\
\text { sector }\end{array}$ \\
\hline Multidisciplinary or cross-functional work teams & $2.44^{* *}$ & $1.19^{*}$ \\
\hline $\begin{array}{l}\text { Job rotation of staff to different departments or other parts of } \\
\text { group }\end{array}$ & $3.20^{*}$ & 0.40 \\
\hline Financial incentives for employees to develop new ideas & $1.28^{*}$ & $3.02^{*}$ \\
\hline Non-financial incentives for employees to develop new ideas & $2.01^{* *}$ & $-4.85^{* *}$ \\
\hline Training of employees on how to develop new ideas or creativity & -0.78 & $2.80^{* *}$ \\
\hline $\begin{array}{l}\text { Firms that hired employees with creative skills and introduced } \\
\text { methods for fostering creativity }\end{array}$ & $1.73^{*}$ & $2.94^{* *}$ \\
\hline Technological intensity of industry & & \\
\hline Medium-low technology intensive manufacturing & $-1.24^{*}$ & - \\
\hline Medium-high technology intensive manufacturing & $-1.08^{*}$ & - \\
\hline High technology intensive manufacturing & $-1.68^{*}$ & - \\
\hline Knowledge intensive services & - & $-3.46^{* *}$ \\
\hline Number of observations & 244 & 271 \\
\hline
\end{tabular}

$(* * *),(* *)$ and $(*)$ indicate statistical significance at $1 \%, 5 \%$ and $10 \%$ levels, respectively.

Findings on methods used to stimulate creativity are somewhat ambiguous. The negative impact of some methods may signal the failure of management to optimally utilise these methods. They may also reflect the weakness of employees to respond to such methods which can have its roots in their education, cultural values, beliefs, etc. In both sectors, the variable representing firms that hired employees with creative skills and introduced methods for fostering creativity is positive and significant, suggesting that compared to firms using only one channel for developing creativity, those firms that employ both channels are more successful in the commercialisation of their innovations.

Together with findings from previous two stages the positive effect of firm size signals that larger firms are more likely to innovate, spend less on innovation but are more successful in commercialisation of their innovations. The intra - group knowledge transfer has positive impact on innovation output in service sector but negative in manufacturing sector. This may be an indication that those firms which are part of a larger group are producers of standardised products, a finding that is consistent with existing literature on the behaviour of firms in transition economies (Stojcic et al. 2013). However, it may also indicate that recipient firms lack absorptive capacity to benefit from knowledge transfer.

In both sectors the inverse Mill's ratio is statistically significant which confirms our expectation of the existence of selection bias. The innovation input, i.e., expenditure on innovation has a positive impact on innovation output in both sec- 
tors. The higher productivity of firms has a negative and significant effect in the service sector and no effect in the manufacturing sector, reflecting the risk averse nature of firms in CEECs and their propensity towards the quiet-life hypothesis. A positive sign is found on variable representing the introduction of radical innovations (the so-called 'new to the world') in manufacturing sector suggesting that the intensity of competition in this sector forces firms to introduce radical innovation in order to differentiate themselves from their rivals.

Unlike previous two stages, the market orientation of firms is significant in both manufacturing and service sectors albeit with different sign. While in manufacturing sector orientation towards the EU market increases innovation output and orientation on other foreign markets has negative impact, the opposite holds for the service sector. This may signal differences in market demand and the nature of competition. Firms competing on the EU market may find it more difficult to seize market share of their rivals and have to continuously come up with new products than those competing on markets of other countries (especially less developed ones). The reported finding may also be an indicator of differences in the internationalisation strategies of firms in different markets. The negative impact of subsidies at both the EU and national levels on the innovation output is consistent with previous findings on the innovation behaviour of firms in European countries and questions the efficiency of existing subsidy schemes (Hashi and Stojcic, 2013; Radicic and Pugh, 2013). Finally, a positive sign is observed in both sectors on variables controlling for firms that introduced organisational and marketing innovations.

\subsection{Innovation and Productivity}

The final stage of the innovation process is the productivity equation, highlighting the ultimate impact of innovation activities on firm performance and competitiveness (Table 7). In terms of creative skills we observe positive signs only on graphic, arts, layout and advertising skills in manufacturing sector and on market research skills in services. Engineering skills have a negative impact on productivity in services. Among methods to stimulate creativity, only the training of employees to develop new ideas has a positive impact on the productivity of firms. 
Table 7:

\section{PRODUCTIVITY EQUATION}

\begin{tabular}{|l|c|c|}
\hline & $\begin{array}{c}\text { Manufacturing } \\
\text { sector }\end{array}$ & $\begin{array}{c}\text { Service } \\
\text { Sector }\end{array}$ \\
\hline Firm size & $0.21^{* *}$ & 0.06 \\
\hline Part of a group & $0.55^{* * *}$ & $0.49^{* * *}$ \\
\hline Innovation output & $1.16^{* * *}$ & $-0.50^{* *}$ \\
\hline Market orientation & $-0.56^{* *}$ & -0.15 \\
\hline Main market - EU & -0.05 & -0.03 \\
\hline Main market - other countries & & \\
\hline Highly important effects of innovation & -0.05 & -0.21 \\
\hline Increased range of goods and services & -0.04 & -0.14 \\
\hline Replacement of outdated products and processes & 0.01 & $0.33^{* *}$ \\
\hline Entry into new markets or increased market share & 0.19 & $0.56^{* * *}$ \\
\hline Improvement in the quality of goods and services & -0.26 & $-0.55^{* * *}$ \\
\hline $\begin{array}{l}\text { Improvement in the flexibility for production of goods and } \\
\text { services }\end{array}$ & -0.10 & 0.07 \\
\hline Increased capacity for production of goods and services & 0.002 & 0.11 \\
\hline Reduction in unit labour costs & 0.04 & $-0.31^{* *}$ \\
\hline Reduction in unit material and energy costs & 0.15 & 0.05 \\
\hline Reduced environmental impact & -0.03 & $0.27^{* *}$ \\
\hline Improved health and safety of employees & $-0.35^{*}$ & -0.12 \\
\hline Highly important objectives of organisational innovations & -0.17 & -0.21 \\
\hline $\begin{array}{l}\text { Reduction in time required for response to customer or } \\
\text { supplier needs }\end{array}$ & -0.35 & 0.02 \\
\hline Improved ability to develop new products or processes & -0.34 & -0.05 \\
\hline Improved quality of goods and services & -0.03 & 0.13 \\
\hline Reduced unit costs of production & -0.28 & 0.003 \\
\hline Improved communication or information sharing. & 0.12 & \\
\hline Highly important objectives of marketing innovations & 0.04 & 0.10 \\
\hline Increase or maintaining of market share & & -0.07 \\
\hline Introduction of products to new customer groups & -0.17 \\
\hline Introduction of products to new geographical markets & & \\
\hline Creative skills of employees & & -0.03 \\
\hline Graphic, arts, layout and advertising skills & & \\
\hline Design of objects and services & & \\
\hline Multimedia & & \\
\hline
\end{tabular}


Table 7 - Continued

\begin{tabular}{|l|c|c|}
\hline Web design & 0.04 & 0.20 \\
\hline Software development & -0.09 & -0.02 \\
\hline Market research & -0.12 & $0.27^{*}$ \\
\hline Engineering & -0.14 & $-0.22^{*}$ \\
\hline Mathematics, statistics and database management & -0.01 & 0.07 \\
\hline Methods to stimulate creativity & 0.001 & 0.05 \\
\hline Brainstorming sessions & -0.43 & 0.03 \\
\hline Multidisciplinary or cross-functional work teams & -0.06 & -0.33 \\
\hline $\begin{array}{l}\text { Job rotation of staff to different departments or other parts } \\
\text { of group }\end{array}$ & 0.32 & -0.03 \\
\hline Financial incentives for employees to develop new ideas & -0.51 & -0.05 \\
\hline $\begin{array}{l}\text { Non-financial incentives for employees to develop new } \\
\text { ideas }\end{array}$ & -0.47 & $0.53^{* *}$ \\
\hline $\begin{array}{l}\text { Training of employees on how to develop new ideas or } \\
\text { creativity }\end{array}$ & 0.29 & -0.08 \\
\hline $\begin{array}{l}\text { Firms that hired employees with creative skills and } \\
\text { introduced methods for fostering creativity }\end{array}$ & & \\
\hline Technological intensity of industry & 0.27 & - \\
\hline Medium-low technology intensive manufacturing & -0.11 & - \\
\hline Medium-high technology intensive manufacturing & - & - \\
\hline High technology intensive manufacturing & 244 & 271 \\
\hline Knowledge intensive services & & 0.07 \\
\hline Number of observations & & \\
\hline
\end{tabular}

$(* * *),(* *)$ and $(*)$ indicate statistical significance at $1 \%, 5 \%$ and $10 \%$ levels, respectively.

It seems that the productivity of firms in manufacturing increases with firm size, and is higher in both sectors if they belong to a group. While the impact of innovation output on productivity of firms in manufacturing sector is positive the coefficient for service sector has negative sign suggesting that firms in this sector are more efficient in the production of existing services. Among variables reflecting market orientation, only the coefficient of EU-orientation is significant with a negative sign in the manufacturing sector. In the service sector, the entry into new markets and increased market share, improvements in the quality of goods and services and improved health and safety of employees have a positive impact on the productivity of firms. 


\section{Conclusion}

The mechanisms of the innovation process and ways to motivate firms to speed up this process have occupied academics and policy makers for some time. While factors influencing the innovation process have been studied intensively there has been no attempt to address the role of creativity within a multi-stage framework of innovation behaviour of firms. As there is a widespread consensus that creativity presents the seedbed of innovation, the empirical investigation of the relationship between different aspects of creativity and innovation activities of firms is an important step forward towards the identification of measures which can speed up the innovation process, and thus improve the competitiveness of firms.

The empirical investigation of this paper makes several contributions to the literature. Firstly, the paper presents the first attempt to explore the role of creativity at different stages of the innovation process. Second, the modelling of creativity was undertaken in a way which allows for the investigation of its direct influence on productivity as well as its indirect impact through innovation activities of firms. Third, unlike most of the existing studies, the modelling approach has identified and explored the impact of two aspects of creativity on innovations - the decision of managers to hire employees with certain creative skills and to introduce a variety of methods to stimulate the generation of new ideas and creativity.

It is evident that creative activities have their strongest impact on transformation of innovation expenditure into innovation output, and the decision of firms to innovate. Such finding is consistent with earlier predictions: creative ideas form the basis of the decision to innovate while creative efforts may open new ways for market success of innovations in the innovation throughput stage, the transformation of innovation inputs into innovation output. It seems, however, that the impact of creativity on productivity mostly takes place indirectly through innovations as most of variables representing creativity are not significant in the productivity equation.

There are substantial variations across stages of innovation process and sectors in channels through which creativity affects the innovation process. It appears that hiring personnel with creative skills is the dominant channel in the early stages of the innovation process. However, when it comes to transformation of innovation inputs into innovation output, the positive impact of both creative skills and methods of stimulating creativity prevails. Our findings also show that some aspects of creativity may have a negative impact on innovation activities of firms. While this may signal failures in managerial decision-making about hiring of personnel, it may also be an indication of the discrepancy between formal qualifications and actual skills of employees. The negative impact of methods for fostering 
of creativity may reflect the inability of managers to properly apply these methods to their employees or the unresponsiveness of employees to these methods due to their personal background.

The paper suffers from a number of limitations, the most important being the fact that the analysis is undertaken on the sample of firms from one country. Moreover, the dataset does not allow for the inclusion of another important channel for the influence of creativity on innovations - the design dimension- or the impact of the firm and society's creative environment. Another weakness of the analysis arises from the cross section nature of the data which makes it impossible to consider the dynamic process of innovation and to distinguish between short and long run impacts of creativity on innovation activities and performance of firms. Future researches would have to address these challenges.

\section{REFERENCES}

Aldridge, T., Audretsch, D., B., (2010). Does policy influence the commercialization route? Evidence from National Institutes of Health funded scientists, Research Policy, 39 (5): 583-588.

Amabile T., M., Mueler J., S. and Archambault, S. (2000). Detailed event narativa analysis (DENA) coding scheme, Harward Business School Working Paper 03-080.

Amabile, T. M. (1988). A model of creativity and innovation. In B. M. Staw \& L. L. Cummings (Eds.), Research in organizational behavior, 10 (pp. 123-167). Greenwich, CT: JAI.

Andari, R. Bakshi, H, Hutton, W., O'Keefe, A. and Schneider, P. (2007): Staying ahead? The economic contribution of the creative industries. London: Department for Culture, Media and Sport.

Baron, R.A., and Tang, J., (2011); The role of entrepreneurs in firm-level innovation: Joint effects of positive affect, creativity, and environmental dynamism. Journal of Business Venturing, 26: 49-60.

Baucus, M., Norton, W., Baucus, D. and Human, S., (2008): Fostering creativity and innovation without encouraging unethical behaviour. Journal of Business Ethics. 81: 97-115.

Bjork, J. and Magnusson, M. (2009): Where do Good Innovation Ideas Come From? Exploring the Influence of Network Connectivity on Innovation Idea Quality, Journal of Product Innovation Management, 26 (6): 662-670.

Camagni, R. (1991). 'Local milieu', uncertainty and innovation networks: Towards a new dynamic theory of economic space. In: R. Camagni (Ed.), Innovation Networks: Spacial Perspectives (pp. 121-143). London: Belhaven Press 
Castellacci, F., (2008). Technological paradigms, regimes and trajectories: Manufacturing and service industries in a new taxonomy of sectoral patterns of innovation, Research Policy, 37: 978-994.

Cereda, M., Crespi, G., Criscuolo, Haskel, J., (2005). Design and Company Performance: Evidence from the Community Innovation Survey, DTI Report.

Chapain, C., Cooke, P., De Propris, L., MacNeill, L. and Mateos-Garcia, J. (2010): Creative clusters and innovation: Putting creativity on the map. London: National Endowment for Science, Technology and the Arts.

Chesbrough, H., (2006). “Open Innovation: A New Paradigm for Understanding Industrial Innovation," in Henry Chesbrough, Wim Vanhaverbeke, and Joel West, eds., Open Innovation: Researching a New Paradigm. Oxford: Oxford University Press: 1-12.

Cohen, W. and Levintahl, D. (1990): Absorptive Capacity: A New Perspective on Learning and Innovation, Administrative Science Quarterly, 35 (1): 128-152.

Cohen, W.M., Nelson, R.R. and Walsh, J.P. (2002). Links and impacts: the influence of public research on industrial R\&D, Management Science, 48: 1-23.

Crepon, B., Duguet, E., Mairesse, J. (1998). Research, innovation, and productivity: an econometric analysis at the firm level. NBER Working Paper 6696 (downloaded from http://www.nber.org/papers/w6696 on 30 August 2013).

Eisenbeis, A. and Boerner, S. (2013): A Double-edged Sword: Transformational Leadership and Individual Creativity. British Journal of Management, 24(1), pp. 54-68.

Ettlie, J. E. and Rosenthal, S. R. (2011). Service versus Manufacturing Innovation. Journal of Product Innovation Management, 28: 285-299.

Florida, R. (2003): Cities and the creative class. City and Community, 2(1): 3-19

Halpern, L. and Murakozy, B. (2012). Innovation, Productivity and Exports, Economics of Innovation and New Technology, The Case of Hungary, 12(2): 151-173.

Hashi, I., Stojcic, N., (2013) The impact of innovation activities on firm performance using a multi-stage model: Evidence from the Community Innovation Survey, Research Policy, 42(2): 353-366.

Jelinčić, D A. and Žuvela, A. (2013): Što nas čini različitima? Kreativni Zagreb na putu prema kreativnoj Europi, Media Studies, 4(7), pp. 75-92.

Kale, P., Singh, H. and Perlmutter, H. (2000): Learning and protection of proprietary assets in strategic alliances: building relational capital. Strategic Management Journal 21 (3): 217-237.

Klomp, L. and van Leeuwen, G. (2001). Linking Innovation and Firm Performance: A new Approach, International Journal of the Economics and Business, Taylor and Francis Journal, 8(3): 343364.

Koestler, A. (1964). The Act of Creation, London: Hutchinson \& Co.

Lee, N. and Drever, E. (2012): Creative industries, occupations and innovation in London. Big Innovation Centre Working Paper, University of Lancaster. 
Lee, N. and Rodriguez-Pose, A. (2013). Creativity, Cities and Innovation, CEPR Discussion Paper, No. DP9598.

Loof, H. and Heshmati, A. (2002). Knowledge capital and performance heterogeneity: a firm-level innovation study. International Journal of Production Economics 76: 61-85.

Loof, H. and Heshmati, A. (2006). On the relationship between innovation and performance: a sensitivity analysis. Economics of Innovation and New Technology 4-5: 317-344.

on August 22, 2013.

OECD (2005). Oslo Manual. Guidelines for collecting and interpreting innovation data.

Marrocu, E. and Paci, R. (2012): Education or Creativity: What Matters Most for Economic Performance? Economic Geography 88: 369-401.

Nahapiet, J. and Ghoshal, S. (1998): Social Capital, Intellectual Capital and the Organizational Advantage, The Academy of Management Review 23 (2): 242-266.

Rašić Bakarić, I., Bačić, K. and Božić, Lj., (2015): Mapping of Cultural and Creative Industries in the Republic of Croatia, Zagreb: The Institute of Economics, Zagreb, project study (mimeo).

Schumpeter, J.A. (1934). The Theory of Economic Development: An Inquiry into Profits, Capital, Credit, Interest, and the Business Cycle. Harvard University Press, Cambridge, MA.

Stojcic, N., Hashi, I. and Telhaj, S. (2013). Restructuring and competitiveness: Empirical evidence on firm behaviour in new EU member states and candidate countries, Eastern European Economics, 51(4): 84-107.

Swan, P. and Birke, D. (2005). How do Creativity and Design Enhance Business Performance? A Framework for Interpreting the Evidence, 'Think Piece' for DTI Strategy Unit, downloaded from

http://tna.europarchive.org/20081112122150/http://www.berr.gov.uk/files/file14794.pdf on 24 November 2013).

Švob-Đokić, N, (2005): The Emerging Creative Industries in Southeastern Europe, collection of papers from the course "Managing Cultural Transitions: Southeastern Europe - The Impact of Creative Industries" organized by the Inter-University Centre, Dubrovnik, May 8-15, 2005, Zagreb: Institute for International Relations.

Villalba, E. (2010). Monitoring Creativity at an Aggregate Level: a proposal for Europe, European Journal of Education, 45(2): 314-330.

Von Hippel, E. (1988). The Sources of Innovation, New York, NY, Oxford University Press.

Yoshida, D.T., Sendjaya, S., Hirst, G. and Cooper, B. (2014): Does servant leadership foster creativity and innovation? A multi-level mediation study of identification and prototypicality, Journal of Business Research, 67(7), pp. 1395 - 1404.

Yusuf, J., (2009): From Creativity to Innovation, Technology in Society 31 (1): 1-8. 
Table Al:

\section{SUMMARY OF FINDINGS ON CREATIVITY VARIABLES}

\begin{tabular}{|l|c|c|c|c|c|c|c|c|c|}
\hline Sector & \multicolumn{3}{|c|}{ Manufacturing } & \multicolumn{5}{|c|}{ Services } \\
\hline Innovation stage & 1 & 2 & 3 & 4 & 1 & 2 & 3 & 4 \\
\hline Creative skills & & & & & & & & \\
\hline Graphics, arts and advertising & NS & - & + & + & - & NS & + & NS \\
\hline Design of objects and services & + & NS & + & - & + & NS & - & NS \\
\hline Multimedia & NS & NS & - & NS & + & NS & + & NS \\
\hline Web design & NS & - & + & NS & - & NS & - & NS \\
\hline Software development & + & NS & NS & NS & + & NS & + & NS \\
\hline Market research & + & NS & - & NS & NS & NS & + & + \\
\hline Engineering & + & NS & + & NS & NS & NS & - & - \\
\hline Mathematics, statistics and database management & NS & + & - & NS & NS & NS & - & NS \\
\hline Methods to stimulate creativity & & & & & & & & \\
\hline Brainstorming sessions & - & NS & - & NS & NS & NS & + & NS \\
\hline Multidisciplinary/cross-functional teams & NS & NS & + & NS & NS & NS & + & NS \\
\hline Job rotations & NS & NS & + & NS & NS & NS & NS & NS \\
\hline Financial incentives to employees & NS & NS & + & NS & NS & NS & + & NS \\
\hline Non-financial incentives to employees & NS & NS & + & NS & NS & + & - & NS \\
\hline Training of employees on creativity & + & NS & NS & NS & NS & NS & + & + \\
\hline
\end{tabular}

\section{KREATIVNOST, INOVACIJE I REZULTATI POSLOVANJA PODUZEĆA: DOKAZI IZ IZRANJAJUĆEG TRANZICIJSKOG GOSPODARSTVA}

Sažetak

Unatoč široko rasprostranjenom konsenzusu da kreativnost tvori sjeme inovacijskog procesa, dostupna literatura u ovom području tek je djelomično istražila doprinos pojedinih dimenzija kreativnosti različitim stadijima inovacijskog procesa te mehanizme korištene od strane menadžmenta za poticanje kreativnosti zaposlenika. U radu se koristi kompleksna metodologija kako bi se rasvijetlila uloga kreativnosti u različitim stadijima inovacijskog procesa od odluke o inoviranju i visini ulaganja u inovacije preko transformacije inovacijskih inputa u outpute do utjecaja inovacijskog outputa na proizvodnost. Višestupanjski CDM model koji obuhvaća različite dimenzije kreativnosti te prakse poticanja oslobađanja kreativnog potencijala zaposlenika primijenjen je na podatke iz baze Community Innovation Survey. U modeliranju upravljanja kreativnosti razlika je napravljena između odluke poduzeća o zapošljavanju kreativnih pojedinaca i metoda korištenih za poticanje kreativnosti poput interdisciplinarnih radnih skupina, financijskih inicijative i treninga u svrhu poticanja kreativnosti. Rezultati upućuju na važnost kreativnih vještina zaposlenika i pojedinih tehnika poticanja kreativnosti u inovacijskom procesu i poticanju uspješnosti poduzeća. Također ukazuju na sektorske razlike u utjecaju kreativnosti na inovacije.

Ključne riječi: kreativnost, inovacije, proizvodnost, ponašanje poduzeća, CDM model 